NASA/TM-2000-210251

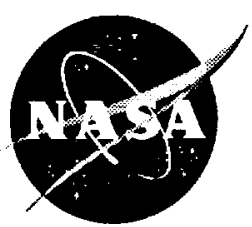

Efficiency and Regulation of Commercial Low Power DC/DC Converter Modules at Low Temperatures

Malik E. Elbuluk

University of Akron, Akron, Ohio

Scott Gerber and Ahmad Hammoud

Dynacs Engineering Company, Inc., Brook Park, Ohio

Richard L. Patterson

Glenn Research Center, Cleveland, Ohio 
The NASA STI Program Office . . . in Profile

Since its founding, NASA has been dedicated to the advancement of aeronautics and space science. The NASA Scientific and Technical Information (STI) Program Office plays a key part in helping NASA maintain this important role.

The NASA STI Program Office is operated by Langley Research Center, the Lead Center for NASA's scientific and technical information. The NASA STI Program Office provides access to the NASA STI Database, the largest collection of aeronautical and space science STI in the world. The Program Office is also NASA's institutional mechanism for disseminating the results of its research and development activities. These results are published by NASA in the NASA STI Report Series, which includes the following report types:

- TECHNICAL PUBLICATION. Reports of completed research or a major significant phase of research that present the results of NASA programs and include extensive data or theoretical analysis. Includes compilations of significant scientific and technical data and information deemed to be of continuing reference value. NASA's counterpart of peerreviewed formal professional papers but has less stringent limitations on manuscript length and extent of graphic presentations.

- TECHNICAL MEMORANDUM. Scientific and technical findings that are preliminary or of specialized interest, e.g., quick release reports, working papers, and bibliographies that contain minimal annotation. Does not contain extensive analysis.

- CONTRACTOR REPORT. Scientific and technical findings by NASA-sponsored contractors and grantees.
- CONFERENCE PUBLICATION. Collected papers from scientific and technical conferences, symposia, seminars, or other meetings sponsored or cosponsored by NASA.

- SPECIAL PUBLICATION. Scientific, technical, or historical information from NASA programs, projects, and missions, often concerned with subjects having substantial public interest.

- TECHNICAL TRANSLATION. Englishlanguage translations of foreign scientific and technical material pertinent to NASA's mission.

Specialized services that complement the STI Program Office's diverse offerings include creating custom thesauri, building customized data bases, organizing and publishing research results ... even providing videos.

For more information about the NASA STI Program Office, see the following:

- Access the NASA STI Program Home Page at http://www.sti.nasa.gov

- E-mail your question via the Internet to help@sti.nasa.gov

- Fax your question to the NASA Access Help Desk at (301) 621-0134

- Telephone the NASA Access Help Desk at (301) 621-0390

- Write to: NASA Access Help Desk NASA Center for AeroSpace Information 7121 Standard Drive Hanover, MD 21076 
NASA/TM-2000-210251

\section{Efficiency and Regulation of Commercial Low Power DC/DC Converter Modules at Low Temperatures}

Malik E. Elbuluk

University of Akron, Akron, Ohio

Scott Gerber and Ahmad Hammoud

Dynacs Engineering Company, Inc., Brook Park, Ohio

Richard L. Patterson

Glenn Research Center, Cleveland, Ohio

Prepared for the

35th Intersociety Energy Conversion Engineering Conference sponsored by the American Institute of Aeronautics and Astronautics Las Vegas, Nevada, July 24-28, 2000

National Aeronautics and

Space Administration

Glenn Research Center 


\section{Acknowledgments}

This work has been supported by a grant from the Low Temperature Electronics Group at the NASA Glenn Research Center to the University of Akron and under the NASA Contract NAS3-98008

(Dynacs Engineering Company, Inc.)

Available from

NASA Center for Aerospace Information

National Technical Information Service 5285 Port Royal Road

7121 Standard Drive

Springfield, VA 22100

Hanover, MD 21076

Price Code: A03

Price Code: A03 


\section{AIAA-2000-2800 \\ EFFICIENCY AND REGULATION OF COMMERCIAL LOW POWER DC/DC CONVERTER MODULES AT LOW TEMPERATURES}

\author{
Malik E. Elbuluk \\ University of Akron \\ Akron, Ohio 44325-3904
}

\author{
Scott Gerber \& Ahmad Hammoud \\ Dynacs Engineering Company, Inc. \\ Brook Park, Ohio 44135
}

\author{
Richard L. Patterson \\ National Aeronautics and Space \\ Administration \\ Glenn Research Center \\ Cleveland, Ohio 44135
}

\begin{abstract}
DC/DC converters that are capable of operating at cryogenic temperatures are anticipated to play an important role in the power systems of future NASA deep space missions. Design of these converters to survive cryogenic temperatures will improve the power system performance, and reduce development and launch costs.

At the NASA Glenn Research Center Low Temperature Electronics Laboratory, several commercial off-the-shelf DC/DC converter modules were evaluated for their low temperature performance. Various parameters were investigated as a function of temperature, in the range of $20^{\circ} \mathrm{C}$ to $-190^{\circ} \mathrm{C}$. Data pertaining to the efficiency and voltage regulation of the tested converters is presented and discussed.
\end{abstract}

\section{BACKGROUND}

Electrical power components and systems for future NASA space missions, such as outer planetary exploration and deep space probes, must operate reliably and efficiently in very low temperature environments. For example, inter-planetary probe launched 10 explore the rings of Satum would experience a temperature of about $-183^{\circ} \mathrm{C}$. Table I shows the operational temperatures for an unheated spacecraft in the vicinity of each of the outer planets. These spacecraft include deep space probes, planetary orbiters and landers, and surface exploratory instrumentation. Presently, spacecraft operating in these regions utilize Radioisotope Heating Units (RHUs) to maintain an operating temperature for the

Copyright 2000 by the American Institute of Aeronautics and Astronautics, Inc. No copyright is asserted in the United States under Title 17, U.S. Code. The U.S. Govemment has a royalty-free license to exercise all rights under the copyright claimed herein for Governmental Purposes. All other rights are reserved by the copyright owner. on-board electronics of approximately $20^{\circ} \mathrm{C}$ [1]. RHUs, which are always on, require associated containment structures and thermal systems such as shutters to maintain the $20^{\circ} \mathrm{C}$ over the course of the entire mission. However, if the electronics were capable of operating at the temperature of the mission environment, the RHUs and their associated structures and thermal systems could be eliminated, reducing system size and weight and thereby reducing system

Table I. Typical operational temperatures for an unheated spacecraft.

\begin{tabular}{|c|c|}
\hline Mission & Temperature ${ }^{\circ} \mathrm{C}$ \\
\hline Mars & -20 to -120 \\
\hline Jupiter & -151 \\
\hline Saturn & -183 \\
\hline Uranus & -209 \\
\hline Neptune & -222 \\
\hline Pluto & -229 \\
\hline
\end{tabular}

development and launch costs, and improving reliability and lifetime [2].

In addition to deep space applications, low temperature electronics have potential uses in terrestrial applications that include magnetic levitation transportation systems, medical diagnostics, cryogenic instrumentation, and super-conducting magnetic energy storage systems. The utilization of power electronics designed for and operated at low temperature is expected to result in more efficient systems than room temperature systems. This improvement results from better electronic, electrical, and thermal properties of materials at low temperatures. In particular, the performance of certain semiconductor devices improves with decreasing temperature down to liquid nitrogen temperature $\left(-196^{\circ} \mathrm{C}\right)$. An example is the power MOSFET which has lower conduction losses at 
low temperature due to the reduction in the drain-tosource resistance $R_{D S}$ (on) resulting from increased carrier mobility.

The Low Temperature Electronics Program at the NASA Glenn Research Center focuses on the research and development of electronic components, circuits and systems suitable for applications where cold temperatures are expected (i.e. deep space). This program has emphasized screening and characterization of candidate components for the development of low temperature electronic circuits $[2,3,4]$. As part of the circuit development, a number of DC/DC converters has been designed or modified to operate from room temperature to $-196^{\circ} \mathrm{C}$ using commercially-available components such as CMOS-type devices and MOSFET switches. These converters ranged in output power from $5 \mathrm{~W}$ to $1 \mathrm{~kW}$ with switching frequencies of $50 \mathrm{kHz}$ to $200 \mathrm{kHz}$. Pulse-width modulation technique was implemented in most of these converters with open- as well as closed-loop control. The topologies included buck, boost, multi-resonant, push-pull and full-bridge configuration $[1,2,5-9]$.

\section{AEROSPACE POWER SYSTEMS}

Most of aerospace power systems are DC-based. Therefore, DC/DC power converters are required to provide the outputs needed for different loads. Such outputs range from $1.5 \mathrm{~V}$ to $15 \mathrm{~V}$ at various power levels. Recently, there has been a tremendous progress in the design of high power density DC/DC converters. Converters that operate at power densities of $50 \%$ or more greater than the available standard conventional converter designs have been developed. This increase in power density is achieved using new designs, advanced devices and components, and packaging techniques. For example, the newly developed synchronous rectifier-based DC/DC converters modules with multi-layer thick film hybrid packaging provide more usable output power without the use of a heat sink than do the conventional, schottky diode based converters with a heat sink and thick-film single layer packaging. However, all of the existing DC/DC converter systems are specified to operate above a minimum temperature of $-40^{\circ} \mathrm{C}$ or $-55^{\circ} \mathrm{C}$. As a result, it was the goal of this work to investigate the performance of these high power density converters and to determine their tolerance to temperatures below their minimum specified temperature.

In this work, six commercial-off-the-shelf modular, low power DC/DC converters, with specifications that might fit the requirements of specific future space missions, have been selected for investigation. Some of the specifications of these converters, which ranged in electrical power from $8 \mathrm{~W}$ to $13 \mathrm{~W}$ and output voltage from $3.3 \mathrm{~V}$ to $5 \mathrm{~V}$, are listed in Table II. The converters were characterized in terms of their performance as a function of temperature in the range of $20^{\circ} \mathrm{C}$ to $-190^{\circ} \mathrm{C}$. The experimental procedures along with the experimental data obtained on the investigated converters are presented and discussed.

Table II. Converter Module Specifications.

\begin{tabular}{|c|c|c|c|c|}
\hline Module & $\begin{array}{c}\text { Input } \\
(\mathrm{V})\end{array}$ & $\begin{array}{c}\text { Output } \\
(\mathrm{V})\end{array}$ & $\begin{array}{c}\text { Power } \\
(\mathrm{W})\end{array}$ & $\begin{array}{c}\text { Temp Range } \\
\left({ }^{\circ} \mathrm{C}\right)\end{array}$ \\
\hline 1 & $9-36$ & 3.3 & 10 & $-40-+60$ \\
\hline 2 & $36-75$ & 5.0 & 10 & $-25-+70$ \\
\hline 3 & $36-72$ & 3.3 & 10 & $-40-+85$ \\
\hline 4 & $18-36$ & 3.3 & 10 & $-40-+70$ \\
\hline 5 & $18-36$ & 3.3 & 13 & $-40-+85$ \\
\hline 6 & $9-36$ & 3.3 & 10 & $-40-+85$ \\
\hline
\end{tabular}

\section{LOW TEMPERATURE TEST SET-UP}

The converters listed in Table II were characterized as a function of temperature from $20^{\circ} \mathrm{C}$ to $-190^{\circ} \mathrm{C}$ in terms of output regulation, efficiency, and input and output current distortions. At a given temperature, these properties were obtained at various input voltages and at different load levels; from no-load to full-load conditions. The tests were performed as a function of temperature using a Sun Systems environmental chamber utilizing liquid nitrogen as the coolant. A temperature rate of change of $10^{\circ} \mathrm{C} / \mathrm{min}$ was used throughout the experiment. The modular converters were tested separately at the following temperatures: $20 ; 0 ;-20 ;-40 ;-60 ;-80 ;-100 ;-120 ;-140 ;-160 ;-180$; and $-190^{\circ} \mathrm{C}$. At every test temperature, the device under test was allowed to soak at that temperature for a period of 30 minutes before any measurements were made. After the last measurement was taken at the lowest temperature, the converters were allowed to stabilize to room temperature and then the measurements were repeated at room temperature to determine the effect of one thermal cycle on the converters.

\section{RESULTS AND DISCUSSIONS}

During the investigations, data was generated for both steady and dynamic states. In this paper, only data pertaining to the steady state efficiency and output 
voltage regulation of the tested converters are presented and discussed.

Figures 1-6 show the output voltage and efficiency of the modules versus temperature for four conditions of input voltage and output load levels. These conditions include: minimum input voltage under light and heavy loads, and maximum input voltage under light and heavy loads. In Figures 1(a) through 6(a), the output voltage variations are shown. An offset in the output voltage at light and heavy loads can be attributed to the resistive drop ( $\cong 70 \mathrm{~m} \Omega$ ) in the wiring from the output terminals of the module to the electronic load where the output voltage was actually measured.

Figure 1(a) shows the output voltage for module \#1. At a given load, the output voltage maintains a steady value from room temperature to $-120^{\circ} \mathrm{C}$. For temperatures beyond $-120^{\circ} \mathrm{C}$, the converter begins to show loss in regulation. For example, the output voltage increases slightly when the input voltage is $36 \mathrm{~V}$ but decreases drastically when the input voltage is $12 \mathrm{~V}$. As expected, the output voltage drops slightly when the load is increased. The effect of temperature on the efficiency of converter module \# I under different input voltage and load conditions is shown in Figure 1(b). In general, the efficiency drops as the temperature is lowered with the heavy load condition having a higher efficiency than that of a light load. For the same loading, the efficiency is higher as the input voltage is decreased. For a given input voltage, the converter has lower efficiency when the load level is low.

Figure 2(a) shows the effect of low temperature on the output voltage of module \#2. It can be seen that the converter maintains a regulated voltage up to $-100^{\circ} \mathrm{C}$. The converter loses regulation between $-100^{\circ} \mathrm{C}$ and $-180^{\circ} \mathrm{C}$, after which the converter ceased to function. The effect of temperature on the efficiency of module \#2 is shown in Figure 2(b). Similar to the voltage regulation, the efficiency of the converter drops rapidly for temperatures below $-100^{\circ} \mathrm{C}$.

In Figure 3(a), module \#3 shows reasonable performance to $-20^{\circ} \mathrm{C}$, but shows complete loss of voltage regulation for temperatures below $-80^{\circ} \mathrm{C}$. It did, however, continue to operate with no regulation down to $-190^{\circ} \mathrm{C}$. This module displayed similar behavior in its efficiency with temperature change as depicted in Figure 3(b).
The output voltage of module \#4 does not exhibit any dependence on either the input voltage or the test temperature at low loads as shown in Figure 4(a). At heavy loads, it does however decrease slightly upon lowering the test temperature regardless of the level of the input voltage. In general, the efficiency of this converter exhibits a slight decrease with decreasing temperature. This reduction becomes apparent at temperatures below $-60^{\circ} \mathrm{C}$, as shown in Figure $4(\mathrm{~b})$.

In Figure 5(a), module \#5 shows excellent output voltage regulation with temperatures down to $-120^{\circ} \mathrm{C}$. The only exception is at $-120^{\circ} \mathrm{C}$ where at minimum input voltage and light load the output voltage increases to over 4 volts. In addition, this module ceased to operate for temperatures below $-120^{\circ} \mathrm{C}$, but regained operation once its temperature rose above $-120^{\circ} \mathrm{C}$. The efficiency of this module (Figure 5(b)) held relatively steady values at heavy load to $-60^{\circ} \mathrm{C}$ and then dropped off as temperature decreased down to $-120^{\circ} \mathrm{C}$.

In Figure 6(a), module \#6 shows relatively good output regulation down to $-120^{\circ} \mathrm{C}$. Beyond that temperature, the output voltage seems to slightly increase as the temperature is decreased further. Its efficiency (Figure 6(b)), however, exhibits a gradual decrease as temperature is decreased. Module \#6 ceased to operate for temperatures below $-180^{\circ} \mathrm{C}$, but regained operation once its temperature rose above $-180^{\circ} \mathrm{C}$.

\section{CONCLUSIONS}

Several commercial-off-the-shelf, low power, DC/DC converter modules were evaluated as a function of temperature in the range of $20^{\circ} \mathrm{C}$ to $-190^{\circ} \mathrm{C}$. Data pertaining to the output voltage regulation and efficiency of the tested converters were presented and discussed.

Test results obtained on the modules have shown that they operated as expected within the manufacturer's specified temperature range as well as with reasonably good performance down to temperatures between $-80^{\circ} \mathrm{C}$ and $-100^{\circ} \mathrm{C}$. For temperatures below $-100^{\circ} \mathrm{C}$, performance was either out of range, erratic, or non-existent.

In all cases, the temperature range for which these modules were designed and specified does not include the severe temperature range for which they were subjected to in this investigation. Additional testing taking into account long-term evaluation and thermal cycling may reveal the potential for extending the 
operational temperature range and/or improving their performance at these very low temperatures through component screening and/or modification to the module design.

\section{REFERENCES}

1. Gerber, S.S., Patterson, R.L., Ray, B. and Stell, C., "Performance of a Spacecraft DC-DC Converter Breadboard Modified for Low Temperature Operation," IECEC 96, Vol.1, 1996, pp. 592-598.

2. Patterson, R.L., Dickman, J.E., Hammoud, A. and Gerber S.S., "Low Temperature Power Electronics Program," NASA EEE Links, Electronic Packaging and Space Parts News, Vol. 4, No. 1, January 1998.

3. Patterson, R.L., Hammoud, A. and Gerber, S.S., "Evaluation of Capacitors at Cryogenic Temperatures for Space Applications," IEEE International Conference on Electrical Insulation, Washington DC, June 7-10, 1998.

4. Hammoud, A., Gerber, S.S, Patterson, R.L. and MacDonald. T., "Performance of Surface-Mount Ceramic and Solid Tantalum Capacitors for Cryogenic Applications," IEEE Conference Phenomena. Atlanta, GA, Oct. 25-28, 1998.
5. Ray, B., Gerber, S.S., Patterson, R.L. and Myers, I.T., "Power Control Electronics for Cryogenic Instrumentation," Advances in Inst. and Control, Vol. 50, Part 1, Int. Soc. for Measurement and Control, 1995, pp. 131-139.

6. Ray, B., Gerber, S., Patterson, R. and Myers, I., "77K Operation of a Multi-Resonant Power Converter," IEEE PESC'95 Record, Vol. 1, pp. 5560 .

7. Ray, B., Gerber, S.S. and Patterson, R.L., "Low Temperature Performance of a Full-Bridge DC-DC Converter," IECEC ‘96, Vol. 1, 1996, pp. 553-559.

8. Ray, B., Gerber, S.S., Patterson, R.L. and Myers, I.T., "Liquid Nitrogen Temperature Operation of a Switching Power Converter," Symp. on Low Temp. Electronics and High Temperature Superconductivity, Vol. 9, 1995, pp. 345-352.

9. Gerber, S.S. Miller, T., Patterson, R.L. and Hammoud, A., "Performance of a Closed-Loop Controlled High Voltage DC/DC Converter at Cryogenic Temperature," IECEC '98, Vol. I, 1998. 


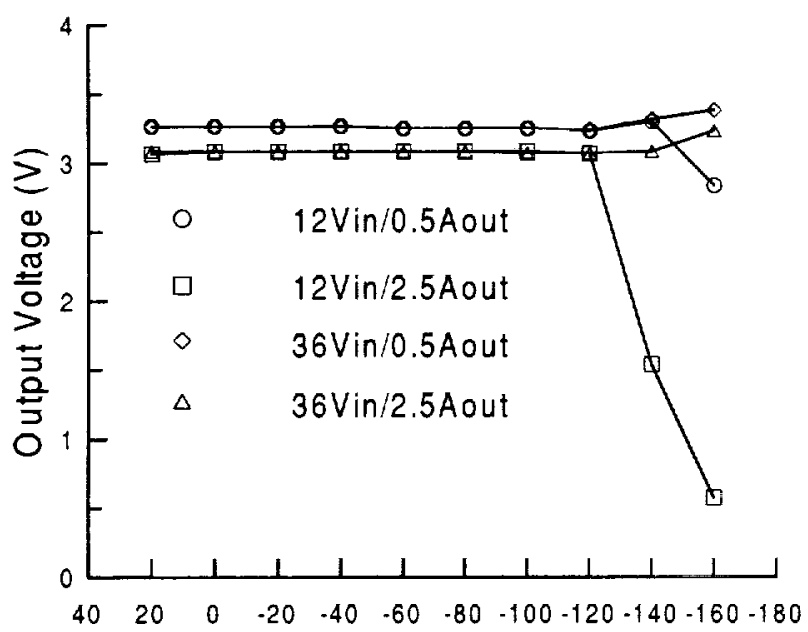

(a) Temperature $\left({ }^{\circ} \mathrm{C}\right)$

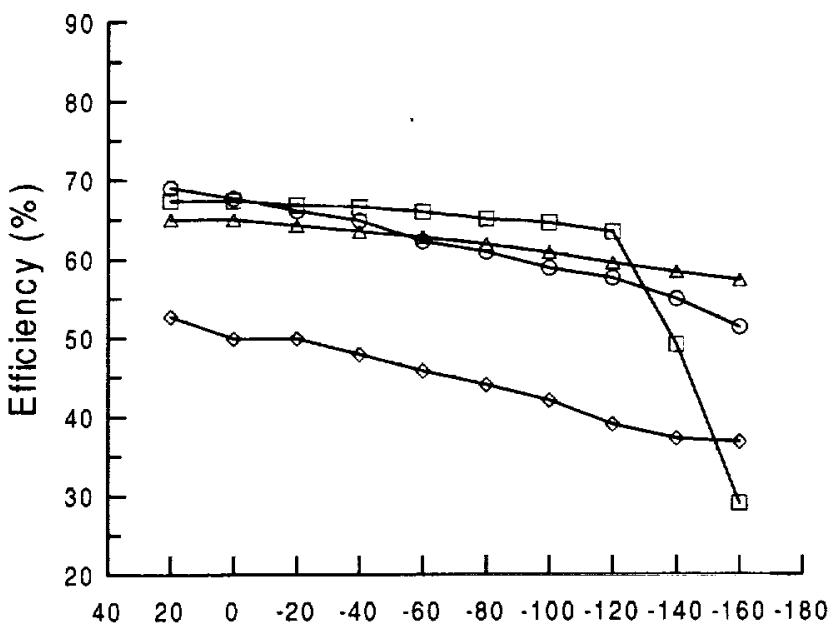

(b) Temperature $\left({ }^{\circ} \mathrm{C}\right)$

Figure 1. Output voltage and efficiency versus temperature for Module \#1.

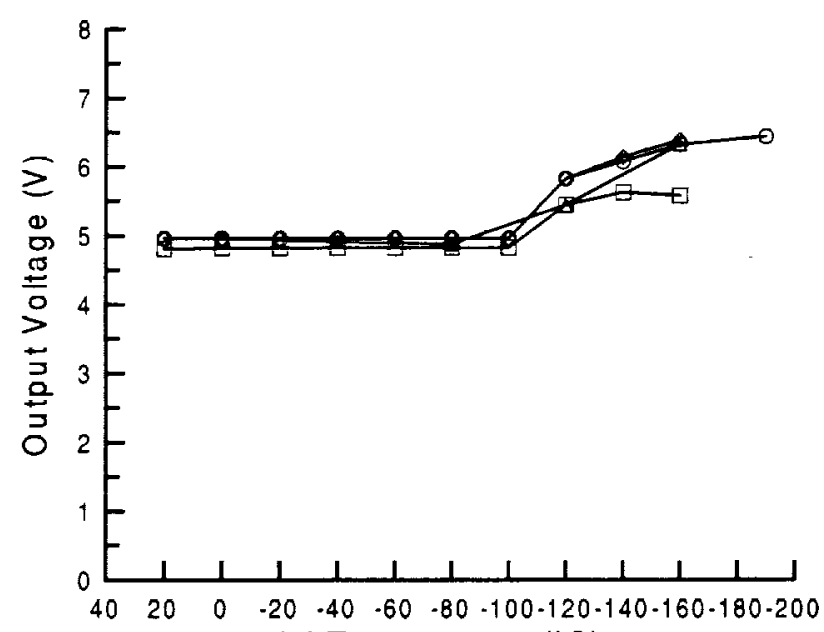

(a) Temperature $\left({ }^{\circ} \mathrm{C}\right)$

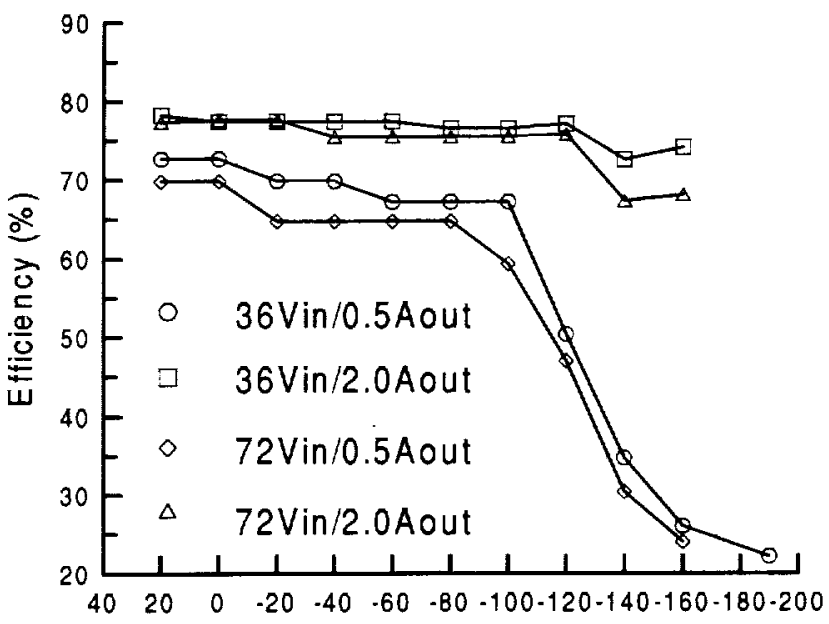

(b) Temperature $\left({ }^{\circ} \mathrm{C}\right)$

Figure 2. Output voltage and efficiency versus temperature for Module \#2.

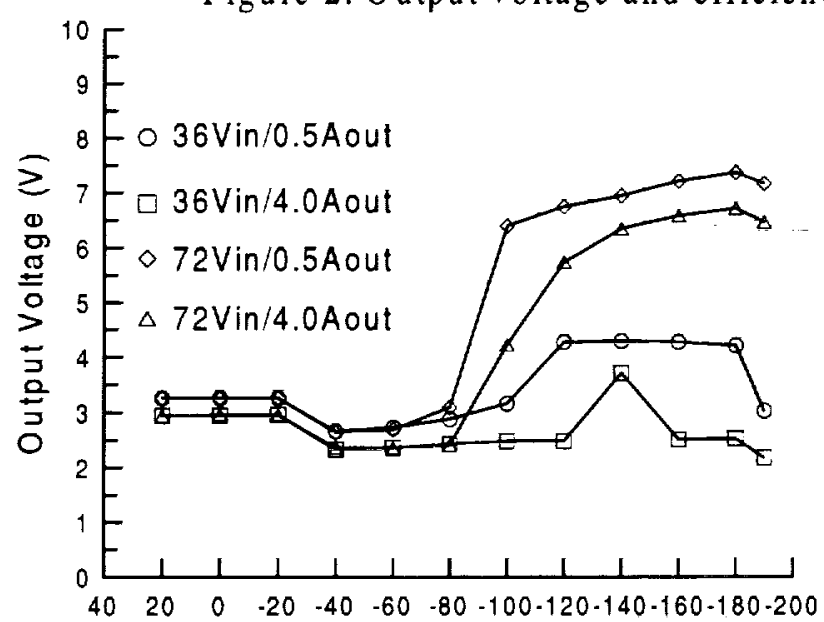

(a) Temperature $\left({ }^{\circ} \mathrm{C}\right)$

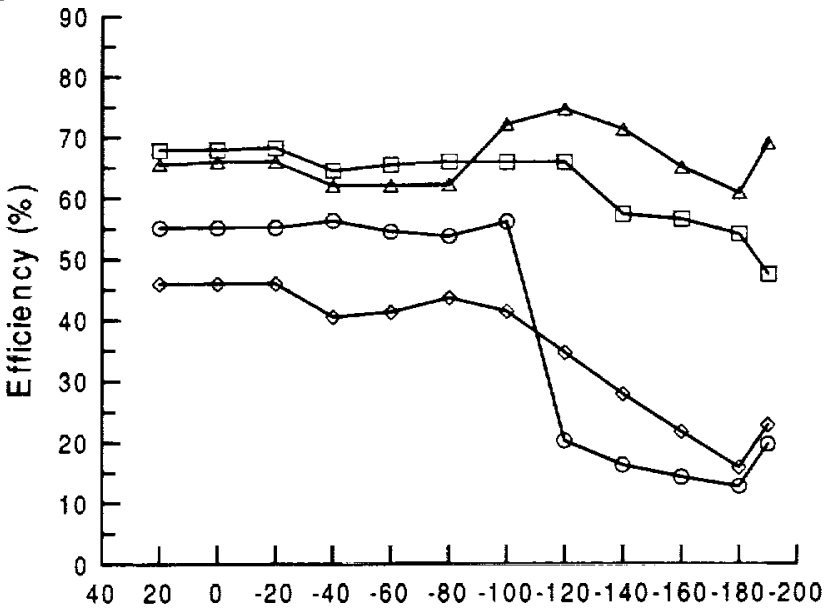

(b) Temperature $\left({ }^{\circ} \mathrm{C}\right)$

Figure 3. Output voltage and efficiency versus temperature for Module \#3. 


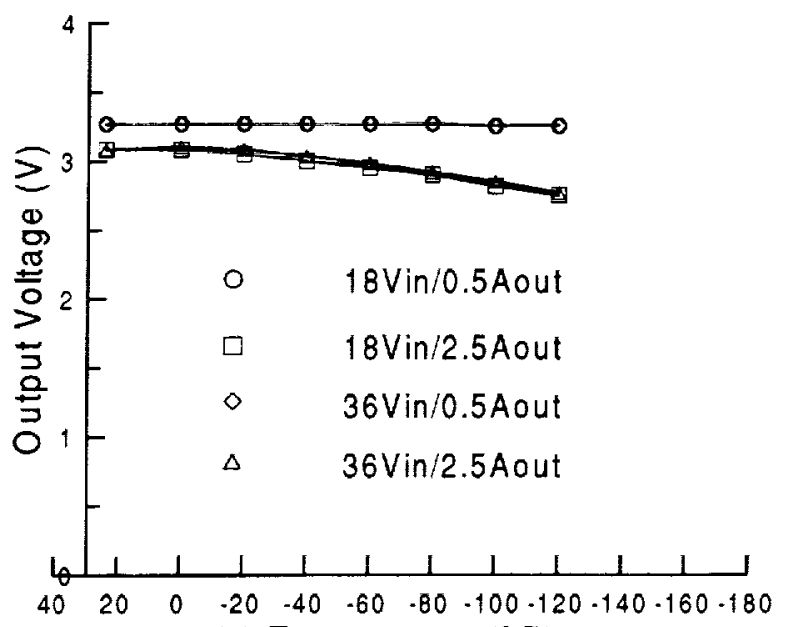

(a) Temperature $\left({ }^{\circ} \mathrm{C}\right)$

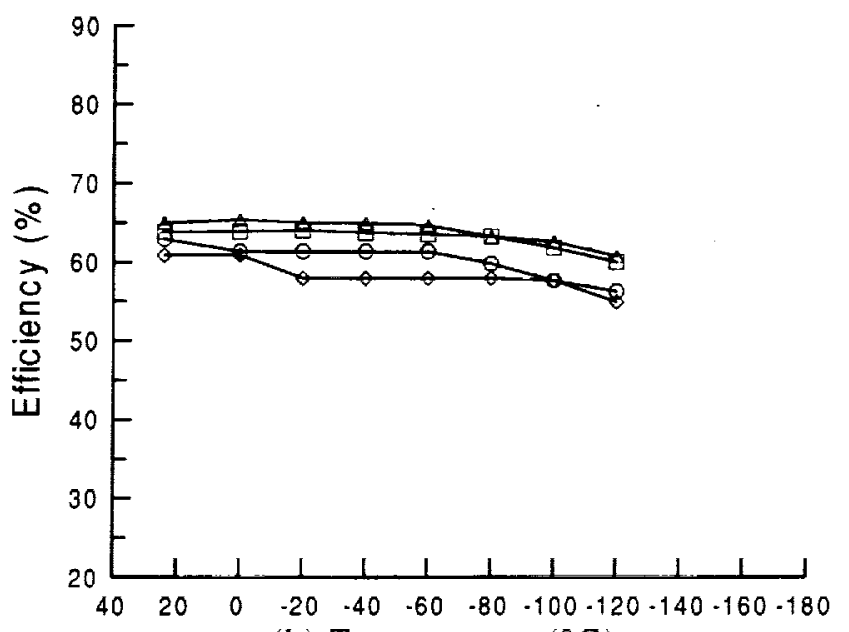

(b) Temperature $\left({ }^{\circ} \mathrm{C}\right)$

Figure 4. Output voltage and efficiency versus temperature for Module \#4.

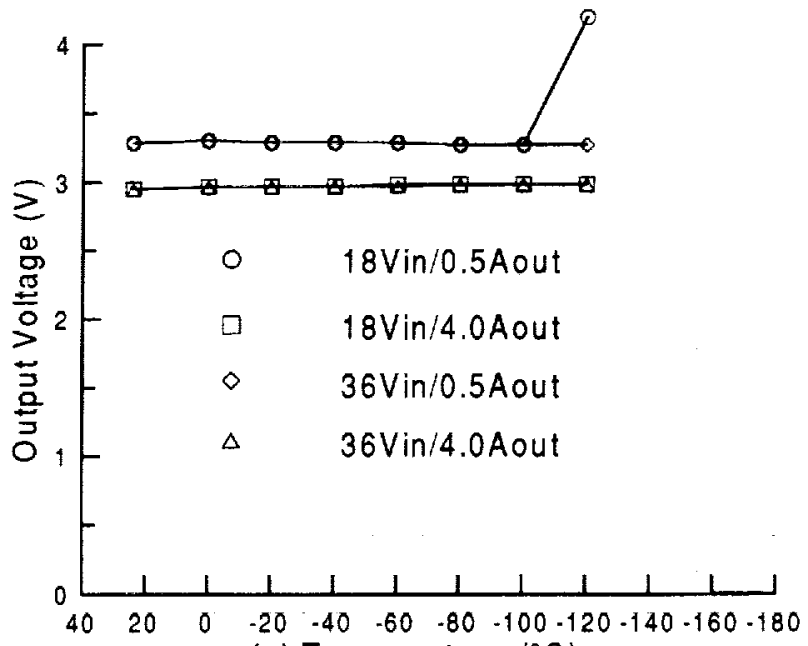

(a) Temperature $\left({ }^{\circ} \mathrm{C}\right)$

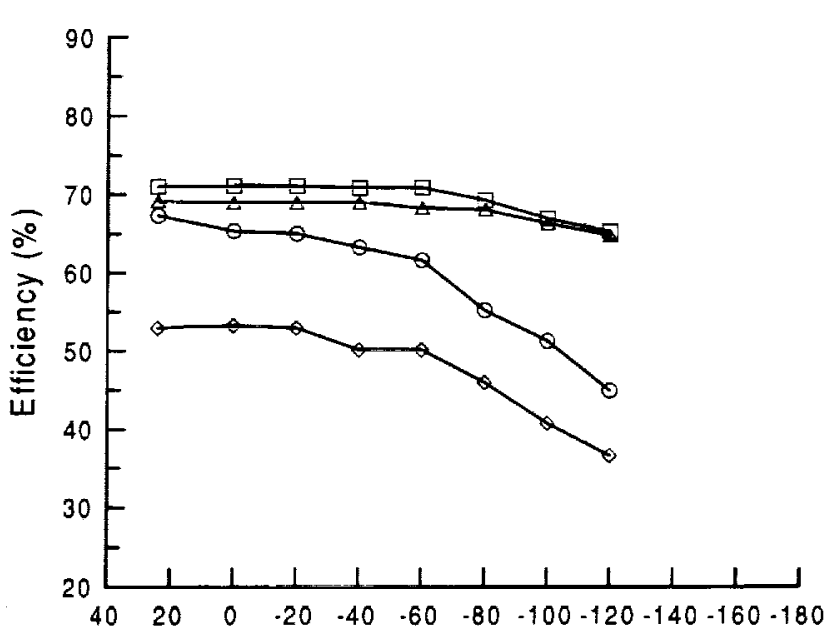

(b) Temperature $\left({ }^{\circ} \mathrm{C}\right)$

Figure 5. Output voltage and efficiency versus temperature for Module \#5.
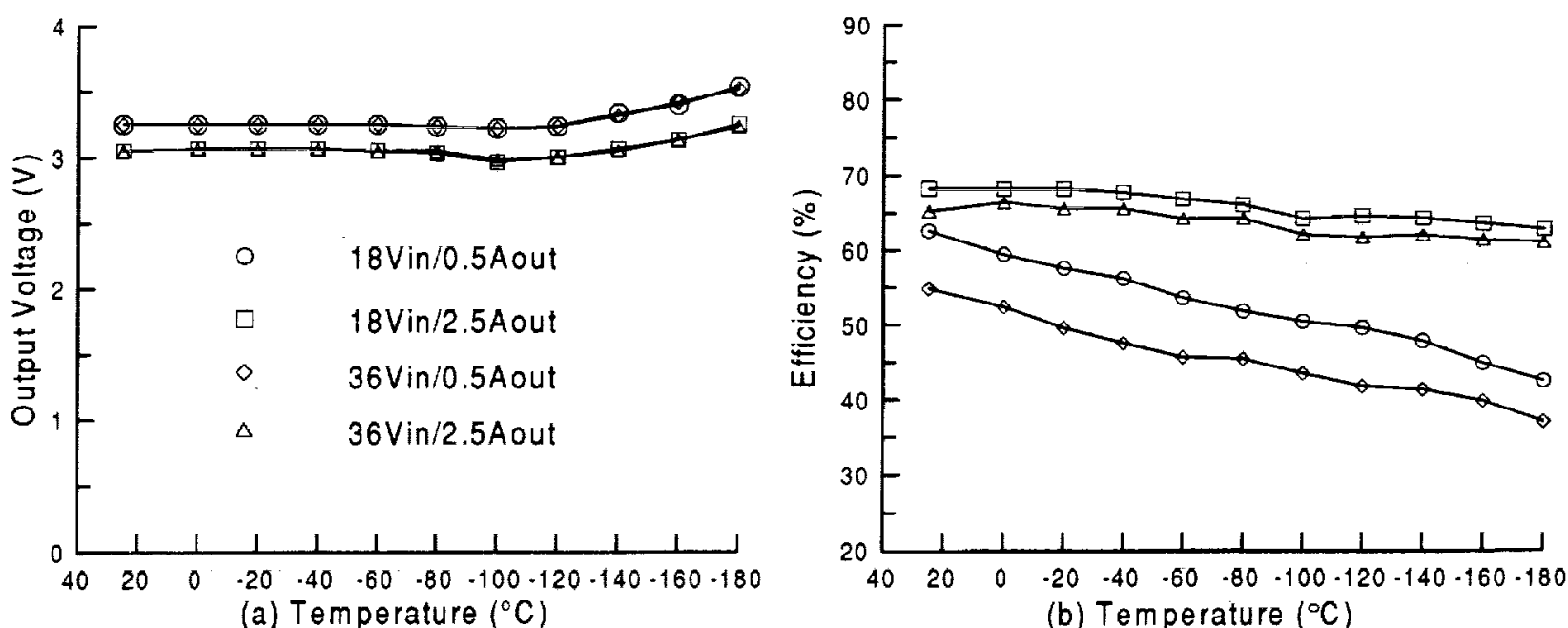

Figure 6. Output voltage and efficiency versus temperature for Module \#6. 
Public reporting burden for this collection of information is estimated to average 1 hour per response, Including the time for revlewing instructions, searching existing data sources, gathering and malntaining the data needed, and completing and reviewing the collection of information. Send comments regarding this burden estimate or any other aspect of this Davis Highway. Suite 1204, Arlington, VA 22202-4302, and to the Office of Management and Budget, Paperwork Reduction Project (0704-0188), Washington, DC 20503.
1. AGENCY USE ONLY (Leave blank)
2. REPORT DATE
July 2000
3. REPORT TYPE AND DATES COVERED
Technical Memorandum

\section{TITLE AND SUBTITLE}

Efficiency and Regulation of Commercial Low Power DC/DC

Converter Modules at Low Temperatures

\section{AUTHOR(S)}

Malik E. Elbuluk, Scott Gerber, Ahmad Hammoud, and Richard L. Patterson

\section{PERFORMING ORGANIZATION NAME(S) AND ADDRESS(ES)}

National Aeronautics and Space Administration

John H. Glenn Research Center at Lewis Field

Cleveland, Ohio 44135-3191

\section{SPONSORING/MONITORING AGENCY NAME(S) AND ADDRESS(ES)}

National Aeronautics and Space Administration

Washington, DC 20546-0001

5. FUNDING NUMBERS

$$
\text { WU-632-6A-1H-00 }
$$

PERFORMING ORGANIZATION REPORT NUMBER

$E-12371$

10. SPONSORING/MONITORING AGENCY REPORT NUMBER

NASA TM-2000-210251

AIAA-2000-2800

\section{SUPPLEMENTARY NOTES}

Prepared for the 35th Intersociety Energy Conversion Engineering Conference sponsored by the American Institute of Aeronautics and Astronautics, Las Vegas, Nevada, July 24-28, 2000. Malik E. Elbuluk, University of Akron, 302 Buchtel Mall, Akron, Ohio 44325; Scott Gerber and Ahmad Hammoud, Dynacs Engineering Company, Inc., 2001 Aerospace Parkway, Brook Park, Ohio 44142; and Richard L. Patterson, NASA Glenn Research Center. Responsible person, Richard L. Patterson, organization code 5480, (216) 433-8166.

12a. DISTRIBUTION/AVAILABILITY STATEMENT 12b. DISTRIBUTION CODE

Unclassified - Unlimited

Subject Categories: 33 and 20

Distribution: Nonstandard

This publication is available from the NASA Center for AeroSpace Information, (301) 621-0390.

\section{ABSTRACT (Maximum 200 words)}

DCIDC converters that are capable of operating at cryogenic temperatures are anticipated to play an important role in the power systems of future NASA deep space missions. Design of these converters to survive cryogenic temperatures will improve the power system performance, and reduce development and launch costs. At the NASA Glenn Research Center Low Temperature Electronics Laboratory, several commercial off-the-shelf dc/dc converter modules were evaluated for their low temperature performance. Various parameters were investigated as a function of temperature, in the range of $20^{\circ} \mathrm{C}$ to $-190^{\circ} \mathrm{C}$. Data pertaining to the efficiency and voltage regulation of the tested converters is presented and discussed.

\section{SUBJECT TERMS}

Power conditioning

17. SECURITY CLASSIFICATION OF REPORT

Unclassified

\section{SECUAITY CLASSIFICATION} OF THIS PAGE Unclassified
15. NUMBER OF PAGES 12 16. PRICE CODE

$\mathrm{A} 03$

20. LIMITATION OF ABSTRACT OF ABSTRACT

Unclassified 